\title{
Performance and Development Strategy for Swamp Buffalo (Bubalus Bubalis) in Serang District Indonesia
}

\author{
Kinerja dan Strategi Pengembangan Kerbau Rawa (Bubalus Bubalis) di Kabupaten Serang Indonesia
}

\author{
Komariah $^{1 *}$, Burhanuddin ${ }^{2}$, M. Dzaki ${ }^{1}$, E. L. Aditia ${ }^{1}$, \& V. A. Mendrofa ${ }^{1}$ \\ ${ }^{1}$ Departement of Animal Production and Technology, Faculty of Animal Science, IPB University, Jln. Agatis \\ IPB Dramaga, Bogor, 16680, Indonesia \\ ${ }^{2}$ Departement of Agribusiness, Faculty of Economics and Management, IPB University, Jln. Kamper IPB \\ Dramaga, Bogor, 16680, Indonesia \\ *Corresponding author: komariah_purjati@yahoo.com \\ (Received 18-01-2020; Revised 18-02-2020; Accepted 29-02-2020)
}

\begin{abstract}
Buffaloes is performance and potensial has ideal as meat-producing livestock, but the population has declined each year. The purpose of this research was to analyze performance and development strategy of swamp buffalo in Serang District. The resarch metodology was using the Body Condition Score (BCS) system and the analysis of Strength, Weakness, Opportunity, Threat (SWOT). The research was conducted in Serang District with a survey method, observation and in-depth interviews to 50 farmers, with the snowball sampling, and reinforced with secondary data from the instance relevant. The research location was determined by purposive sampling. Data obtained from 36 buffaloes randomly with the range of age before and after sexual maturity with a different sex, through direct observation using a frame-size Body Condition Scores (BCS). Analysis BCS calculations using factorial completely randomized design. The analysis showed that bulls have better of Body Condition Scores (BCS) level than cows when subjected to sexual maturity. The result value of the interaction between age and sex was significant $(P<0.05)$, so there were SWOT that differs between the interactions with one another. The SWOT analysis and Quantitative Strategic Planning (QSP): the priority was to improve the weaknesses of alternative strategies to avoid threats, the strategy was to strengthen the organizational/institutional breeders that have a strong bargaining power in order to increase the population of buffaloes and breeder ability.
\end{abstract}

Keywords: body condition score, development strategy, swamp buffaloes

\section{ABSTRAK}

Ternak kerbau memiliki performans yang sangat baik dan berpotensi untuk menghasilkan produksi daging, namun populasi ternak kerbau tiap tahun menurun. Tujuan penelitian ini adalah untuk menganalisis performan dan strategi pengembangan ternak kerbau lumpur di Kabupaten Serang. Penelitian ini menggunakan penilaian BCS (Body Condition Score) dan Analisis SWOT (Strength, Weakness, Opportunity, Threat). Metode penelitian dengan metode survei, observasi dan wawancara kepada 50 peternak kerbau secara snowball sampling serta diperkuat data sekunder dari instasnsi terkait. Lokasi penelitian ditentukan secara purposive sampling. Data primer produktifitas diperoleh dari 36 ekor ternak kerbau secara acak dengan umur sebelum dan sesudah dewasa kelamin dengan jenis kelamin yang berbeda melalui pengamatan langsung frame-size menggunakan BCS (Body Condition Score). Analisis perhitungan BCS menggunakan rancangan acak lengkap pola factorial. Hasil analisis menunjukkankerbau jantan memiliki pertumbuhan tingkat kegemukan yang lebih baik dibanding dengan betina ketika mengalami dewasa kelamin. Nilai signifikan interaksi antara umur dan jenis kelamin berpengaruh nyata $(\mathrm{P}<\mathbf{0 . 0 5})$ sehingga terdapat perbedaan antara interaksi satu dengan yang lainnya. Hasil analisis SWOT dan QSP (Quantitative Strategic Planning): prioritas alternatif strategi yaitu memperbaiki kelemahan untuk menghindari ancaman, strateginya adalah memperkuat organisasi/kelembagaan peternak sehingga memiliki daya tawar yang kuat demi meningkatkan populasi kerbau dan SDM peternak.

Kata kunci : body condition score, kerbau lumpur, strategi pengembangan 


\section{INTRODUCTION}

Serang District in Banten Province, has the potential of developing a high number of buffaloes. The development and cultivation of buffaloes there is still performed by a group of farmers from the community. Serang District has the second highest buffalo population after Lebak, which is 26,385 buffaloes (Parlan 2015). This is a big opportunity for the development of the central region of Serang as buffalo meat producer. This development is very important in order to support the provision of food, especially animal protein from buffalo meat which has high nutritional value. The development can also reduce the number of imported buffalo meat in Indonesia.

The buffalo population in Indonesia has declined each year, in 2011 amounted to 34.74\% (Martondang 2014). It is caused by many influencing factors such a decrease in farming land as source of feed for buffalo, and significant changes in agricultural mechanization. Buffalo maintenance performed by farmers in Indonesia is still using the traditional system. As a result, the frequency of inbreeding is still very high, so that the genetic quality of buffalo population continues to decline, and the progress is slow. The quality of the breed of buffalo can be observed from the performance moreover, necessary for the development, utilization and management improvement efforts in a rational buffalo breeding in the presence of abundant natural resources would be better if reinforced by a strategy. Through the SWOT method, the information examined is from variety of internal factors (strengths and weaknesses) and external factors (opportunities and threats) in the district of Serang in defining a development strategy.

The study looked at the characteristics of the development effort are through the aspects of maintenance management of the buffalo, ownership of cattle, and buffalo obesity levels. Internal factors such as strength and weakness that comes from Serang District, as well as external factors such as opportunities and threats that come from outside the district of Serang, that can affect the development efforts undertaken.

The purpose of this study was to analyze the productivity of swamp buffalo phenotypically, and its development strategy in Serang District. In addition, this development strategy aims to provide inputs to the institution-agency involved in the related policy making on the effort of developing buffalo population.

\section{MATERIALS AND METHODS}

\section{Research Materials and Method}

Materials used include cameras, stationery to record the data results of the study, questionnaires, communication tools, and the tape recorder. Objects used include the primary and secondary data. Primary data includes data obtained directly from the 50 respondents and direct observations. Secondary data includes data from relevant agencies.

The method used for surveying, observing and interviewing farmers used questionnaires that had been prepared from the 50 respondents with a snowball sampling method to obtain the primary data. Snowball sampling is an approach to find informants who have a lot of information (Salghanik and Douglas 2004). Questions in questionnaire include: age, education level, occupation, maintenance management, breeding grounds, the number of livestock ownership, farming constraints and influencing factors in the development of aquaculture buffalo (internal and external). Secondary data were obtained from the relevant agencies such as the Office of Agriculture and Livestock of Serang District, Serang regency, and BPS Banten Province.

The interview result (primary data) were collected and tabulation for analysis on swamp buffalo development strategy in Serang District. Data and information collected were processed and analyzed using the Strenghts Weaknesses Opportunities Threaths (SWOT) analysis. Afterwards, in determining the best strategy used the Matrix Quantitative Strategic Planning (QSP).

\section{Variable}

Body Condition Score (BCS) assessment was conducted on 36 head were used as a sample on male and female buffalo of aged 1-2 and 2-4 years old. According to Alapati et al. (2010), Body Condition Score (BCS) assessment is a subjective method for assessing body fat reserves livestock, especially on herniated discs in the rear livestock and pelvic area. Determining the value of Body Condition Score buffalo using a scale of 1-5 according to Alapati et al. (2010) in Figure 1 indicates: 1 . The base tail to the pin bones; 2. Spinous process (lumbar vertebrae) bones; 3 . The depth of the muscles between the bones of the spinous and transverse processes; 4 . Bone transverse processes (lumbar vertebrae); 5. Between the ribs $12^{\text {th }}$ and $13^{\text {th }} ; 6$. sacral crest bone; 7 . the depth of the muscle between the sacral crest and hooks bone; and 8. the depth of hook and pin bones. Body Condition Score (BCS) is done with the eyes sight, but for buffalos covered with mud, BCS determination should be assisted by holding the buffalo's body which includes: BCS 1 (Very Thin), BCS 2 (Thin), BCS 3 (Medium), BCS 4 (Fat) and BCS 5 (Very Fat).

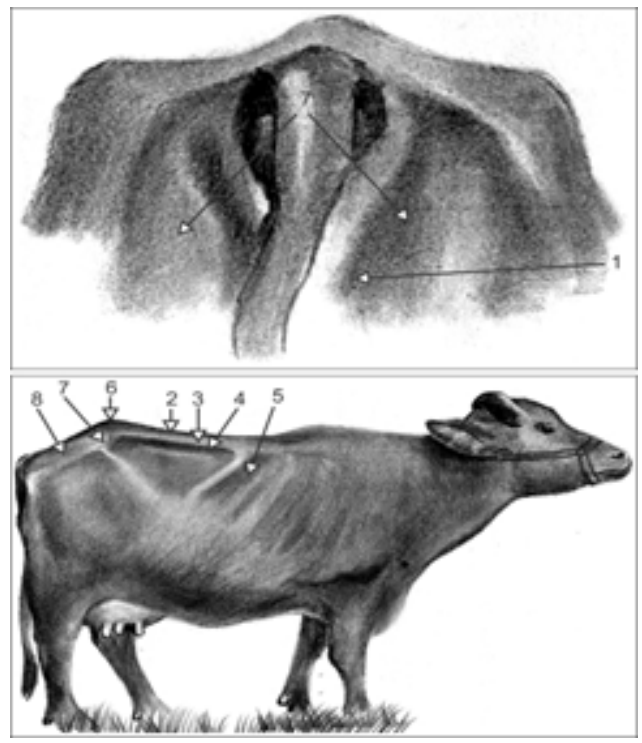

Figure 1. Rate BCS buffalo. Source Alapati et al. (2010) 


\section{Data Analysis}

BCS Analysis. Obesity rate against the swamp buffalo carried by ratings Body Condition Score (BCS) using 2 factors such as age and sex. The data were processed using descriptive analysis and parametric with a completely randomized design (CRD) factorial design (2x2) with 10 repetitions using the equation Gaspersz (1991) as follows:

$$
\text { Yijk }=\mu+\alpha i+\beta j+(\alpha \beta) i j+\epsilon i j k
$$

Description:

$$
\begin{aligned}
& \text { Yijk: : observations by the age of the i-th and } \\
& \mu: \quad \text { : Mean general; } \\
& \text { ai: } \quad \text { : Influence of treatment of age-th; } \\
& \beta \mathrm{j}: \quad \text { : Influence of treatment of sex } \mathrm{j} \text {; } \\
& (\alpha \beta) \quad \text { : ij: Influence the interaction with the i-th } \\
& \text { age sex sex treatment } \mathrm{j} \text {; and } \\
& €: \text { ijk : Effect of measurement error. }
\end{aligned}
$$

Descriptive analysis. The primary and secondary data obtained are presented descriptively qualitative. Descriptive analysis covers aspects relating to the general description of the business of swamp buffaloes environment in Serang District, both internal and external, followed by formulating the strategy of sustainable development. These factors are used as the base in developing the SWOT matrix (Strengths, weaknessess, Opportunities, Threats), IFE Matrix (Internal Factor Evaluation) and EFE (External Factor Evaluation), and QSP Matrix (Quantitative Strategic Planning).

SWOT Analysis. The SWOT Analysis were used to match the internal factors and external key to obtaining four alternative types of strategies include the SO Strategy (strategy of strenghts and opportunities), WO Strategy (strategic of weaknesses and opportunities), ST Strategy (strategic of strengths and threats), and WT Strategy (strategic of weaknesses and threats) (David 2011).

Determination of Score Weight. The Internal Factor Evaluation (IFE) Matrix and External Factor Evaluation (EFE) are used to analyze the internal factors such as the strengths and weaknesses derived from the Serang District, as well as external factors such as opportunities and threats that come from outside the Serang District.

The results of the identification of internal and external factors by weighting and ranking to get a score in a way that is: (a) Making a list of internal and external factors, i.e. strengths, weaknesses, opportunities and threats; (b) giving weights by using paired comparison method (Kinnear and Taylor 2013). Weights were obtained in the range between 0.0 (not important) to 1.0 (the most important). The sum of all weights must be equal to 1.0; (c) Ratings (ratings)1-4 on any factors that indicate these factors are very weak (rank $=1$ ), weak $($ rank $=2)$, strong $($ rank $=3)$, very strong (rank =4); (d) The value of the weighting is then multiplied by the rank of each factor, and all results of multiplications are summed vertically to obtain a total score weighting; (e) Calculation of the total weight score by summing the scores of each variable (David 2011).
Ways of making the QSP matrix: the first column is the filling of matrix with a list of strengths, weaknesses, opportunities and threats of a business; the second column is filled with the weight of each factor; the first line is filled with the alternative strategy of SWOT analysis. Each strategy are being compared to the factor of the strengths, weaknesses, opportunities and threats in order to obtain a score of attractiveness (Attractiveness Scores-US), namely 1 (do not pull), 2 (mildly interesting), 3 (logically draw), 4 (very interesting). The score is then multiplied by the weighting appeal to obtain Total Attractiveness Score (TAS). TAS value of each strategy are summed to obtain the overall appeal of the total amount (SumTotal Attractiveness Score Bags). A higher score indicates a more attractive strategy (David 2011).

\section{RESULTS AND DISCUSSION}

\section{Analysis of Body Condition Score (BCS)}

Body Condition Score is important parameter for the breeder to know which can be observed from the phenotypic appearance. BCS score for breeding stocks are correlated to the conversion of feed into body weight and fertility of livestock. Body condition that has been analyzed by BCS can be used as an indicator in evaluating the nutritional status of owned buffalo, which can be seen on body weight and body weight changes that occur.

Based on the analysis results in Table 1 that BCS score on swamp buffalo, both cow buffalo and bull in Serang District BCS obtain a score of 2-4. Results percentage of BCS score shows that the majority $(69.44 \%)$ buffaloes in Serang District has a score of BCS 3 with moderate body weight category. It can be said that the buffaloes in Serang Regency are sufficiently potential to be developed. BCS score buffalo by age and sex in Serang District obtained the average total score of $2.92 \pm 0.49$. The mean score of the BCS were described in Table 1.

The result showed from the age difference did not significantly affect $\mathrm{BCS}$ score $(\mathrm{P}>0.05)$, as well as to the type of sex did not significantly affect BCS score $(\mathrm{P}>0.05)$. However, the value of the interaction between age and sex shows the real effect $(\mathrm{P}<0.05)$, so that there is a difference between the interactions with one another.

The high percentage of slaughters the productive male and female buffalo becomes one main factor which cause buffalo population to decrease every year with an increasing rate of decline. According to Praharani et al. (2010), a short productive period of reproduction associated with the sale of female buffalo aged $<8$ years as livestock. Female buffalo's productive period is preferably up to at least 10 years of age. Lack of bull and high levels of inbreeding has caused an increasing number of buffalo that are not qualified.

\section{Development Strategy in Serang district}

The Analysis Matrix of Internal Factor Evaluation (IFE). IFE matrix analysis results in Table 2 shows that the factor resulting a major force are those with long experience of raising buffalo with a value of 0.306 . 
Komariah et al.

Jurnal Ilmu Produksi dan Teknologi Hasil Peternakan 8 (2): 54-60

Tabel 1. BCS different mean score of swamp buffalo by age and sex in Serang District

\begin{tabular}{|c|c|c|c|c|c|c|c|c|c|}
\hline \multirow[t]{2}{*}{ Sex } & \multicolumn{6}{|c|}{ BCS at Age Score } & \multicolumn{3}{|c|}{ Mean } \\
\hline & \multicolumn{3}{|c|}{ 1-2 years. } & \multicolumn{3}{|c|}{ 2-4 years. } & & & \\
\hline Females & $3.10 \mathrm{ab}$ & \pm & 0.32 & $2.60 \mathrm{~b}$ & \pm & 0.7 & 2.85 & \pm & 0.59 \\
\hline Males & $2.80 \mathrm{ab}$ & \pm & 0.42 & $3.33 \mathrm{a}$ & \pm & 0.52 & 3.07 & \pm & 0.47 \\
\hline Average & 2.95 & \pm & 0.37 & 2.88 & \pm & 0.61 & 2.92 & \pm & 0.49 \\
\hline
\end{tabular}

Lower case different behind the numbers on the same line indicate significant differences $(\mathrm{P}<0.05)$.

Table 2. Matrix of Internal Factor Evaluation (IFE)

\begin{tabular}{|c|c|c|c|}
\hline Internal Factors & Weight & Rating & Value \\
\hline \multicolumn{4}{|l|}{ Strengths: } \\
\hline 1. Long Experience raising buffalo & 0.094 & 3.25 & 0.306 \\
\hline 2. Serang District became one of the centers of buffalo breeding in Indonesia & 0.083 & 3.00 & 0.249 \\
\hline 3. Buffalo economically valuable & 0.094 & 2.50 & 0.235 \\
\hline 4. Presence of groups of farmers & 0.111 & 2.75 & 0.305 \\
\hline 5. Support on natural resources for raising buffalo & 0.083 & 3.00 & 0.249 \\
\hline \multicolumn{4}{|l|}{ Weaknesses : } \\
\hline 1. Cutting against productive bulls and cow bufalloes is high & 0.133 & 3.25 & 0.432 \\
\hline 2. Population of buffaloes and land husbandry decline each year & 0.111 & 2.75 & 0.305 \\
\hline 3. Traditional maintenance system & 0.089 & 3.25 & 0.289 \\
\hline 4. Human resource of farmers are still low & 0.128 & 3.25 & 0.416 \\
\hline 5. Next young generation of buffalo rancher is low & 0.072 & 3.25 & 0.234 \\
\hline Total & 1.000 & & 3.021 \\
\hline
\end{tabular}

Experience is a must-have early foundation for business continuity for buffalo breeding. The main drawback is the slaughtering against male and female buffalo with high productivity with the value of 0.432 . The slaughtering of buffaloes in Serang District leads to continuous decline of quality of buffaloes.

The Analysis Matrix of External Factor Evaluation (EFE). EFE matrix analysis result in Table 3 shows that factor of the main opportunity is the location which is close to the center of the meat consumers with a value of 0.267 . Location to be one of the main factors to do direct marketing to consumers of meat. While factor of the major threat is the high levels of livestock theft. Theft is a threat that fears breeders to now and need special attention from the local government.

Based on the strengths, weaknesses, opportunities, and threats obtained through internal and external analysis, the alternative strategy can be formulated useing the SWOT matrix. The results of the SWOT matrix analysis obtained six alternative strategies for the development of buffalo breeding in Serang District depicted in Table 3.

Table 3. Matrix of External Factor Evaluation (EFE)

\begin{tabular}{|c|c|c|c|}
\hline Factors External & Weight & Rating & Value \\
\hline \multicolumn{4}{|l|}{ Opportunity: } \\
\hline 1. The need of animal protein increased & 0.094 & 2.50 & 0.235 \\
\hline 2. Diversification of processed meat products increased & 0.078 & 2.50 & 0.195 \\
\hline 3. Price of buffalo meat compete & 0.089 & 2.75 & 0.245 \\
\hline 4. Grand design development of buffalo & 0.094 & 2.25 & 0.212 \\
\hline 5. The location close to the center of meat consumers & 0.089 & 3.00 & 0.267 \\
\hline \multicolumn{4}{|l|}{ Threats: } \\
\hline 1. Competition from the sale and the business of raising buffalo & 0.106 & 3.00 & 0.318 \\
\hline 2. Buffalo meat imports & 0.094 & 3.25 & 0.306 \\
\hline 3. High level of livestock theft & 0.144 & 3.25 & 0.468 \\
\hline 4. Low perception towards buffalo meat & 0.083 & 1.75 & 0.145 \\
\hline 5. Transformation of land farming & 0.128 & 3.00 & 0.384 \\
\hline Total & 1.000 & & 2.774 \\
\hline
\end{tabular}


SO Strategy (Streght-Opportunity). SO strategy resulted in two alternative strategies. Analysis of the first SO strategy is to increase the population of buffaloes. Increasing the population of buffaloes can be done by extending the grazing land, inka optimization (intensification of natural mating), establish guarantees for small farmers to market with a sales price that can compete, and increase the diversity of buffalo meat processed products such as satay, meatballs and dendeng.

SO strategies that optimize and develop both internal capabilities of farmers and utilize natural resources available to improve buffalo business. This can be done by selecting a special area with potential for the development of the government's buffalo farms, utilizing groups of farmers to improve their business and the establishment of the location of the natural attractions that integrate with the cultural hereditary society in raising buffalo in Serang District.

WO Strategy (Weaknesess-Opportunity). Analysis on the WO strategy is to provide education and training on maintaining the quality of livestock, feed selection, uti- lization of the crops, and the marriage arrangement. Forage is available, but its use is still not optimal. Planting quality feed that keeps the major project of the current government as elephant grass and Indigofera as livestock feed.

Selection of high quality feed and residual use of agricultural products can be done with counseling and training provided through government programs. The rest of the agricultural products also can be utilized such as rice straw and corn. Preparation of feed processing technology, as well as to improve the knowledge of farmers. Marriage strategy becomes important in preventing inbreeding marriage, which can be stiffened by the recording of pedigree livestock by farmer groups as well as to maintain the quality of livestock. Gunawan et al. (2010) said, the strategy to be desired as buffalo breeding system includes the application of good breeding practices, improvement of seed quality buffalo breeding, optimizing human resources, policies and regulations on seedling, including financial support by the government.

Table 4. Matrix of Strenghts Weaknesses Opportunities Threats (SWOT)

\begin{tabular}{|c|c|c|}
\hline Internal Factors & $\begin{array}{l}\text { Strengths (S) } \\
\text { 1. Long experience raising buffalo } \\
\text { 2. Serang District become one of the } \\
\text { centers of buffalo breeding in Indonesia } \\
\text { 3. Buffalo is economically valuable } \\
\text { 4. presence of groups of farmers } \\
\text { 5. Natural resources support }\end{array}$ & $\begin{array}{l}\text { Weakness (W) } \\
\text { 1. The high Cutting of buffalo bulls and pro- } \\
\text { ductive female } \\
\text { 2. population of buffaloes and land feed for } \\
\text { livestock decline each year } \\
\text { 3. maintenance system still traditional } \\
\text { 4. human resources of breeders still low } \\
\text { 5. interest of the younger generationto breed } \\
\text { is still low }\end{array}$ \\
\hline \multicolumn{3}{|l|}{ External Factors } \\
\hline $\begin{array}{l}\text { 2. diversification of processed meat prod- } \\
\text { ucts increased } \\
\text { 3. price of buffalo meat compete } \\
\text { 4. grand design of buffalo development } \\
\text { 5. the location close to the center of meat } \\
\text { consumers }\end{array}$ & $\begin{array}{l}\text { Strategy SO: } \\
\text { 1. increase the population of buffaloes } \\
(\mathrm{S} 1, \mathrm{~S} 2, \mathrm{~S} 3, \mathrm{O} 1, \mathrm{O} 2, \mathrm{O} 3) \\
\text { 2. to optimize and develop the HR } \\
\text { breeder and utilize natural resources } \\
\text { available to improve buffalo business } \\
(\mathrm{S} 1, \mathrm{~S} 2, \mathrm{~S} 5, \mathrm{O} 1, \mathrm{O} 3, \mathrm{O} 4, \mathrm{O} 5)\end{array}$ & $\begin{array}{l}\text { Strategy WO: } \\
\text { 1. Provides counseling and training on main- } \\
\text { taining the quality of the livestock, the selec- } \\
\text { tion of feed, utilization of the agricultural } \\
\text { products, and setting the marriage } \\
\text { (W1, W2, W4, O2, O3, O4) }\end{array}$ \\
\hline Threats $(\mathrm{T})$ & Strategy S I: & Strategy W 1: \\
\hline 1. Import of buffalo meat & $\begin{array}{l}\text { 1. Socializing menu of processed meat } \\
\text { and the quality of buffalo meat that is } \\
\text { low in cholesterol and fat than cow }\end{array}$ & $\begin{array}{l}\text { 1. Strengthen organizational/ institutional } \\
\text { breeders that have a strong bargaining power }\end{array}$ \\
\hline 2. rate of cattle rustling high & $(\mathrm{S} 2, \mathrm{~S} 3, \mathrm{~S} 4, \mathrm{~S} 5, \mathrm{~T} 1, \mathrm{~T} 3, \mathrm{~T} 4)$ & (W1, W2, W4, W5, T1, T2, T3, T4) \\
\hline 3. society contention to buffalo meat lower & & $\begin{array}{l}\text { 2. Improved management of buffalo farm to } \\
\text { deal with competitors }\end{array}$ \\
\hline $\begin{array}{l}\text { 4. government policy change buffalo breed- } \\
\text { er became cattle ranchers }\end{array}$ & & (W1, W2, W3, W5, T1, T2, T3, T4) \\
\hline 5. transformation & & \\
\hline
\end{tabular}


ST Strategy (Streght-Threat). Analysis from the ST strategy is to socialize that the menu of processed meat and buffalo meat quality are low in cholesterol and fat than cow.This can be done to build consumers preference towards buffalo meat, aided by government policy which could influence the change in lifestyle of the people to consume buffalo meat.

Issues that have been said that the buffalo meat has a harder texture than the cow is not true, as it is usually done by cutting old aged buffalo that caused consumers to get the meat with a low level of tenderness. In addition, introducing to the public, particularly outside Banten, that buffalo meat contains lower cholesterol and fats than cows, and seeking Serang as producers of cattle and buffalo meat providers.

WT Strategy (Weakness-Threat). Analysis of the WT strategy resulted in two alternative strategies. The first strategy is to strengthen the organization/ institution which makes farmers have a strong bargaining power. This can be done by organizing a program of activities between organizations/ groups of farmers and government premises considered still to gather (saung meetings) and together build a commodity that has a high value. If they already possessed strong internally, automatically human resources development and buffalo livestock population will grow by itself.

Organizational/institutional breeders have an important role as the main actors in moving the livestock development in Indonesia, especially in Serang District. Increased participation of members of the group, the community and the government will increase the dynamism which presents a great opportunity to reach the goal. According to Herman and Swastika (2011), the dynamic group of farmers who have always characterized the activity or interaction.

\section{QSP Analysis (Quantitative Strategic Planning)}

The strategy formulation result from the analysis using the SWOT matrix in principle is very important to support the development of swamp buffalo farm in Serang District. The strategy resulted in six inter-related strategies with other strategies. However, due to limited resources, to be able to perform all of these strategies within the same time it is necessary to order the priority of implementation. The result of the calculation using the matrix QSP can obtaine the total sum value of attractiveness score (STAS) of each strategy. The order of priority of the development strategy of buffaloes in Serang District outlined in Table 5.

The best strategy on the development of swamp buffaloes in Serang District are to strengthen organizational/ institutional breeders that have a strong bargaining power with STAS 19 442. Strengthening of internal as a needed basis to improve sale value. Internal strength will affect the management of the organization/ institution breeders do in overcoming mutual constraints such as the availability of feed, land farming, animal pens and buffalo marketing to consumers.

\section{CONCLUSIONS}

The BCS analysis showed buffalo aged 1-2 years of cow buffallo and bull has BCS value that were not significantly different. Buffalo above 2-4 years old of bull BCS real value is higher than cow buffalo. The Bull buffalo performance is better than cow buffalo when it reaches sexual maturity (2-4 years). The best strategy that can be applied in Serang District is strengthening the organizational/ institutional breeders that have a strong bargaining power.

Table 5. Sequence on buffalo development strategy in Serang District

\begin{tabular}{|c|c|c|}
\hline Alternative Strategies & STAS & Priority \\
\hline Strengthening organizational/ institutional breeders that have a strong bargaining power (WT) & 19442 & 1 \\
\hline $\begin{array}{l}\text { Optimize and develop the internal capability of farmers and utilize natural resources available to } \\
\text { improve buffalo business }(\mathrm{SO})\end{array}$ & 18613 & 2 \\
\hline Increase the population of buffaloes (SO) & 18308 & 3 \\
\hline Improved management of buffalo farm to deal with competitors (WT) & 18267 & 4 \\
\hline $\begin{array}{l}\text { Provide counseling and training on maintaining the quality of the livestock, the selection and preser- } \\
\text { vation of feed, utilization of the agricultural products, and setting marriage (WO) }\end{array}$ & 17431 & 5 \\
\hline $\begin{array}{l}\text { Socializing processed meat menu and the quality of buffalo meat which are low in cholesterol than } \\
\text { cow (ST) }\end{array}$ & 17276 & 6 \\
\hline
\end{tabular}

As for the second WT strategy is to improve the management of buffalo breeding efforts to deal with competitors. Business management is a foundation that must always be repaired and maintained in a business. This management includes the rules that have been made and agreed by an organization/group of farmers from the start of livestock ownership, administration and availability of food, animal pens, the sharing system and marketing. Moreover, this improvement can also be done by improving the quality of human resources which is very important to have a sustainable business, so as to compete in producing something that is expected.

\section{REFERENCES}

Alapati, A., S. R. Kappa, S. Jeepalyam, S. M. P. Ranggappa, \& K. R. Yemireddy. 2010. Development of the body condition score system in Murrah buffaloes: Validation through ultrasonic assessment of body fat reserves. J. Vet. Sci. 11 (1): 1-8.

David, F. R. 2011. Strategic Management: Concepts. 13th ed. Salemba Four, Jakarta,

Gaspersz, V. 1991. Analysis Techniques in Experimental Research. Trasindo, Bandung. 
Gunawan, E. Romjali \& C Talib. 2011. Buffalo breeding development policies to support self-sufficiency in beef/buffalo. Inside: Talib C, Herath H, Matondang RH, Prahrani L, editor. Acceleration buffalo breeding and development through local knowledge and technological innovation to succeed buffalo and cow meat self-sufficiency and the improvement of public welfare farm, In : Proceedings of the National Seminar and Workshop Buffalo. Lebak, 2-4 November 2010. Pp 241-245. (In Indonesian with abstract in English).

Herman, K. S. \& D. K. S. Swastika. 2011. Strengthening farmer groups: a first step improving the welfare of farmers. JAK. 9 (4): 371-390.

Kinnear, T. C. \& Jr. Taylor. 1992. Marketing Research.3rd ed. Jakarta (ID): PT Erlangga.
Martondang, R. H. 2014. The potensial of buffloes as meat producer of national. J. Resc. Agri. Dev. 33(2).

Parlan. 2015. Blogroll will expand buffalo breeding. http:// www.bantenprov.go.id/read/berita-pimpinan/1795/ pemprov-banten-akan-perluas-pembibitan-kerbau. (accessed: 21 February 2017).

Prahrani L., E. Juarini \& C. Talib. 2010. Population and Development of Livestock Development Strategy Buffalo. Wartazoa. 20 (3): 119-129.

Salganik M. J. \& D. H. Douglas. 2004. Sampling and estimation in hidden Populations using Respondent-Driven Sampling. A Social Method. 34(1): 193-239. 